\title{
How glycine betaine induces tolerance of cucumber plants to salinity stress?
}

\author{
A. ESTAJI*, H.M. KALAJI ${ }^{* * * * *,+}$, H.R. KARIMI ${ }^{*}$, H.R. ROOSTA* ${ }^{*}$ and S.M. MOOSAVI-NEZHAD ${ }^{*}$ \\ Department of Horticultural Sciences, Faculty of Agriculture, Vali-E-Asr University of Rafsanjan, Iran* \\ Institute of Technology and Life Sciences (ITP), Falenty, Al. Hrabska 3, 05-090 Raszyn, Poland** \\ Department of Plant Physiology, Faculty of Agriculture and Biology, Warsaw University of Life Sciences, \\ Nowoursynowska 159, 02-776 Warsaw, Poland $d^{* * *}$ \\ Department of Horticultural Sciences, Faculty of Agriculture and Natural Resources, University of Tehran, \\ Karaj, Iran $^{\#}$
}

\begin{abstract}
The mechanism of osmoprotectant action on photosynthesis process is still not well known, especially under salt stress. The objective of this study was to evaluate and explain the effect of glycine betaine (GB) on photosynthetic efficiency and other physiological parameters of cucumber plants grown under salinity stress. Our results indicated that salinity decreased chlorophyll and carotenoids content, $\mathrm{Ca}^{2+}$ and $\mathrm{K}^{+}$concentrations, and quantum yield parameters, such as probability that a trapped exciton moves an electron in to the electron transport chain beyond $\mathrm{Q}_{\mathrm{A}}$, quantum yield of electron transport from $\mathrm{Q}_{\mathrm{A}}$ to $\mathrm{Q}_{\mathrm{B}}$ in PSII, quantum yield of reduction of end electron acceptors in PSI, performance index for the photochemical activity, total performance index for the photochemical activity, trapping per reaction centers, and other parameters related to primary photochemical reactions of PSII. However, the exogenously applied GB increased most of tested parameters including the total soluble carbohydrate, proline and GB content, and $\mathrm{Ca}^{2+}$ and $\mathrm{K}^{+}$concentrations, under salt stress. We suggest that GB can play an essential role as regulator to improve photosynthetic efficiency and thus yield of cucumber plants under salt stress conditions. At the level of photosynthesis process, the application of exogenous GB indirectly enhanced the performance of the photosynthetic machinery of cucumber plant due to the reduction of the dissipated light energy, as heat, and the increase of primary reactions of photosynthesis efficiency.
\end{abstract}

Additional key words: Cucumis sativus; Kautsky curve; OJIP transient; osmolyte; photosystem; pigment.

\section{Introduction}

Salinity is a well-documented problem affecting agricultural production worldwide, in particular in arid and semiarid conditions. Plant responses to salinity stress are complex and depend on time and duration of salt stress application and stage of plant growth (Cramer et al. 2001, Estaji et al. 2018). Salinity stress is not only attributed to stomata closure and reduced transpiration, but also to a decrease in the water potential of plant tissues and reduction in ion uptake, especially $\mathrm{K}^{+}$and $\mathrm{Ca}^{2+}$. It was also found that glycine betaine (GB) content and maximum quantum yield parameters were directly reduced under salinity stress (Cha-um et al. 2006). Consequently, due to these physiological changes, some morphological changes, such as decrease in leaf number and total leaf area, were

\section{observed (Vassileva et al. 2012, Estaji et al. 2018).}

Photosynthesis is one of the most important processes that is affected in plants under saline conditions. This is due to salinity influence on photosynthetic enzymes activity, reduction of PSII and PSI activities, and chlorophylls (Chl) and carotenoids (Car) contents (Stepien and Klobus 2006). The former is highly susceptible to stress, and its activity is significantly impaired or even partially stopped under stress conditions (Brestič and Živčák 2013). In addition, changes in thylakoid membranes under stress conditions cause photosynthesis deterioration (Sharkey and Zhang 2010). Salt stress may also lead to a damage of D1 and D2 units in the reaction centers (De Las Rivas and Barber 1997).

Recently, in addition to the costly biochemical analysis,

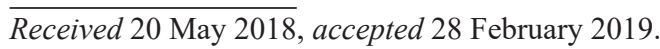

${ }^{+}$Corresponding author; phone: +48 664943 484, e-mail: hazem@kalaji.pl

Abbreviations: Chl - chlorophyll; $\mathrm{DM}$ - dry mass; $\mathrm{ET}_{0} / \mathrm{RC}$ - electron transport flux per $\mathrm{RC} ; \mathrm{F}_{0}-$ minimal fluorescence yield of the dark-adapted state; $F_{m}$ - maximal fluorescence of the dark-adapted state FM - fresh mass; $F_{v}$ - maximal variable fluorescence; $\mathrm{F}_{\mathrm{v}} / \mathrm{F}_{\mathrm{m}}$ - maximal quantum yield of PSII photochemistry; GB - glycine betaine; $\mathrm{PI}_{\mathrm{abs}}$ - performance index for the photochemical activity; $\mathrm{PI}_{\text {tot }}$ - total performance index for the photochemical activity; RC - reaction center; SM - normalized area (related to the number of electron carriers per electron transport chain); TChl - total chlorophyll; $\mathrm{TR}_{0} / \mathrm{RC}$ - trapped energy flux per RC; TSC - total soluble carbohydrate; $\mathrm{V}_{\mathrm{I}}$ - relative variable fluorescence at I-step (30 ms after the start of actinic light pulse); $\mathrm{V}_{\mathrm{J}}-$ relative variable fluorescence at J-step ( $2 \mathrm{~ms}$ after the start of actinic light pulse); $\Phi_{\mathrm{Do}}$ - quantum yield of energy dissipation; $\varphi_{\mathrm{E} T 20}$ - quantum yield of electron transport from $\mathrm{Q}_{\mathrm{A}}$ to $\mathrm{Q}_{\mathrm{B}}$ in PSII; $\Phi_{\mathrm{P}_{\mathrm{o}}}$ - maximum quantum yield of primary PSII photochemistry; $\Phi_{\mathrm{RE} 10}$ - quantum yield of reduction of end electron acceptors in PSI; $\Psi_{0}$ - probability that a trapped exciton moves an electron in to the electron transport chain beyond $\mathrm{Q}_{\mathrm{A}}$. 
the analyses of Chl fluorescence signals have been used as a quick, reliable, powerful, and simple tool to provide information about the status of PSII and for assessment of photosynthetic electron transport (Kalaji et al. 2014, Osório et al. 2014, Stirbet et al. 2018). Chl fluorescence, produced by the $\mathrm{Chl}$ molecule after excitation by light, is a nondestructive biomarker for the assessment of stress effects on PSII (Strasser et al. 2000). In this method, a photosynthetic sample (spot of leaf), is adapted in darkness (e.g., for $15 \mathrm{~min})$ ) and then illuminated with high intensity light pulse. A rapid rise in $\mathrm{Chl}$ fluorescence value may be observed (labelled as $\mathrm{O}, \mathrm{K}, \mathrm{J}, \mathrm{I}$ and $\mathrm{P}$ letters). The lowest value of Chl fluorescence (the minimal fluorescence $-\mathrm{F}_{0}$ ), the fluorescence value at $2 \mathrm{~ms}\left(\mathrm{~F}_{\mathrm{J}}\right)$, the fluorescence value at about 20-30 ms $\left(F_{I}\right)$, and a peak of fluorescence $\left(F_{P}\right)$ or the maximal fluorescence $\left(\mathrm{F}_{\mathrm{m}}\right)$, which is subsequently followed by a slow decline in fluorescence intensity to a steady-state level of fluorescence, can also be detected. This induction is called Chl $a$ fluorescence induction or Kautsky induction curve (Kautsky and Hirsch 1931, Strasser et al. 2004). The shape of the O-J-I-P curve may be changed during stress conditions (Xia et al. 2004). The JIP-test is highly used for the response of plant species to stress conditions (Percival and Henderson 2003, Kalaji et al. 2011, Roosta et al. 2018, Stirbet et al. 2018). Salinity and drought decreased maximal variable fluorescence $\left(F_{v}\right)$ and maximal quantum yield of PSII photochemistry $\left(\mathrm{F}_{\mathrm{v}} / \mathrm{F}_{\mathrm{m}}\right)$ and increased maximal fluorescence of the dark-adapted state $\left(\mathrm{F}_{\mathrm{m}}\right)$ and minimal fluorescence yield of the darkadapted state $\left(\mathrm{F}_{0}\right)$ (Zhao et al. 2007). The works of Razavi et al. (2008) (strawberry), Hussain and Reigosa (2011), and Petridis et al. (2012) (olive) showed that Chl fluorescence signals increased with increasing stress level.

It is already known that exogenous application of some organic solutions, such as GB and proline, improves plant tolerance to stress conditions. These compounds of low molecular mass and high solubility are synthesized under stress conditions (Serraj and Sinclair 2002). GB is one of the most abundant ammonium compounds which is synthesized in chloroplasts in response to stress (Yang et al. 2003). It also plays a key role in protection of thylakoid membranes, maintaining of photosynthetic enzyme activity and photosynthesis (Genard et al. 1991). It has been also proved that the application of GB helps plants keep osmotic balance, stabilize photosynthetic pigments, and protect the plant cells against the disorders caused by salt stress (Gadallah 1999). Denaxa et al. (2012) have shown that exogenous GB application enhanced the Chl $a$, $b$, and total $\mathrm{Chl}$ content in olive trees under drought stress. In addition, it has been observed that plants treated with GB showed better growth and lesser $\mathrm{Na}^{+}$accumulation under salt stress (Lutts 2000).

The objective of our study was to analyze the effect of GB application on functioning of photosynthetic apparatus in cucumber plants under salt stress and to understand the correlation between the Chl content and fluorescence, proline, GB, total soluble carbohydrate (TSC) content, ion uptake, and dry mass under salt stress before and after this application.

\section{Materials and methods}

Plant material and growth conditions: The study was carried out in an experimental greenhouse of Vali-e-Asr University of Rafsanjan, Iran, during 2014-2015. Cucumber (Cucumis sativus var. Sultani) was sown in pots (3.9L) filled with a $1: 1$ of perlite:cocopeat mixture. Afterwards, pots were kept in the greenhouse with temperature of $25 \pm 2{ }^{\circ} \mathrm{C}$. Plants were protected from pest with pesticides and irrigated with Hoagland solution containing: $5 \mathrm{mM} \mathrm{KNO}_{3}$, $2.5 \mathrm{mM} \mathrm{Ca}\left(\mathrm{NO}_{3}\right)_{2}, 2 \mathrm{mM} \mathrm{MgSO}, 1 \mathrm{mM} \mathrm{KH} \mathrm{KO}_{4}, 7 \mu \mathrm{M}$ $\mathrm{MnCl}_{2}, 0.7 \mu \mathrm{M} \mathrm{ZnSO}_{4}, 0.8 \mu \mathrm{M} \mathrm{CuSO}_{4}, 0.8 \mu \mathrm{M} \mathrm{Na}_{2} \mathrm{MoO}_{4}$, $25 \mu \mathrm{M}$ Fe-EDDHA, and $2 \mu \mathrm{M} \mathrm{H}_{3} \mathrm{BO}_{3}$. The nutrient solution $(\mathrm{pH} 6.5 \pm 0.1)$ was renewed every $3 \mathrm{~d}$ and the substrate was partially rinsed with distilled water to avoid nutrient accumulation. The GB was applied three times (14, 28 , and $35 \mathrm{~d}$ after germination) on the foliage of plants at the concentrations of 0,50 , and $100 \mathrm{mM}$. Salinity treatments began $21 \mathrm{~d}$ after germination and lasted for 20 d. The salinity treatment was applied along with Hoagland solution at three concentrations $(0,50$, and $100 \mathrm{mM} \mathrm{NaCl})$. Sampling for all parameters was done at the end of the salinity period.

Dry mass: At the end of the experiment, plants were pulled out from the soil and divided into shoots and roots and weighed immediately after harvesting. The samples were dried in an oven for $72 \mathrm{~h}$ at $70^{\circ} \mathrm{C}$ and the dry mass (DM) of samples was measured.

Chl and carotenoid (Car) pigments: $\mathrm{Chl}$ pigments (Chl $a$, $\mathrm{Chl} b$, and total Chl) and Car contents were determined according to Lichtenthaler (1987). At the end of the experiment, three fully expanded leaves from each pot (one leaf from each plant) were collected and wrapped in aluminum foil to avoid degradation of pigments by light. The extract was prepared from fresh leaves $(1 \mathrm{~g})$ by grinding in a cold mortar and pestle together with $10 \mathrm{ml}$ of $80 \%$ aqueous acetone. After filtering, absorbance of centrifuged extracts was measured at 470,646, and $663 \mathrm{~nm}$ using a spectrophotometer (U-2000, Hitachi Instruments, Tokyo, Japan).

Proline and total soluble carbohydrate (TSC) content: To determine the free-proline concentration, $0.5 \mathrm{~g}$ of leaves was homogenized in $5 \mathrm{~mL}$ of $95 \%$ ethanol. The insoluble fraction of the extract was washed with $5 \mathrm{~mL}$ of $70 \%$ ethanol. The extract was centrifuged at 3,500 rpm for 10 min and the supernatant was preserved at $4^{\circ} \mathrm{C}$ for the proline determination. An aliquot of this supernatant was taken and was placed in a bath at $100^{\circ} \mathrm{C}$ after adding reactive ninhydrin acid reagent (ninhydrin, $6 \mathrm{M}$ phosphoric acid, and glacial acetic acid at 99\%). After $45 \mathrm{~min}$, the tubes were cooled and absorbance at $520 \mathrm{~nm}$ was determined (U-2000, Hitachi Instruments, Tokyo, Japan). Proline concentration was calculated with a standard curve and expressed as $\mu \mathrm{g} \mathrm{g}^{-1}$ (FM) (Paquin and Lechasseur 1979).

In order to determine TSC, $0.1 \mathrm{ml}$ of the extract prepared in ethanol (alcoholic extracts made for proline) was mixed with antron (200 mg of antron plus $100 \mathrm{ml}$ 
of $72 \%$ sulphuric acid). The tubes were kept in a bath at $100^{\circ} \mathrm{C}$ for $10 \mathrm{~min}$. Then they were cooled and absorbance at $625 \mathrm{~nm}$ was measured by U-2000 ( Hitachi Instruments, Tokyo, Japan). The concentration of soluble sugars was calculated using the standard curve and the results were expressed as $\mathrm{mg} \mathrm{g}^{-1}(\mathrm{FM})$.

Glycine betaine content: Contents of GB were quantified as described previously by Arakawa et al. (1990). Leaf samples $(0.5 \mathrm{~g})$ were ground and homogenized with $25 \mathrm{ml}$ of distillated water and shaken for $48 \mathrm{~h}$ at $25^{\circ} \mathrm{C}$. Extracts were
Chl fluorescence was measured before (on $20 \mathrm{~d}$ ) and after salt stress application using the portable photosynthetic efficiency analyzer (PEA, Hansatech Instruments Ltd., UK). After samples (fully developed leaves) dark adaptation for $15 \mathrm{~min}$, Chl fluorescence parameters were measured and further ones were calculated (see table below) with the help of the 'PEA Plus' software package (version 1.02). Basic Chl fluorescence parameters derived from the fluorescence parameters were as follows (Brestič and Živčák 2013):

\section{Basic parameters derived from the extracted data}

$\mathrm{F}_{0} \quad$ Minimum fluorescence, when all PSII RCs are open (O-step of OJIP transient)

$\mathrm{F}_{\mathrm{m}} \quad$ Maximum fluorescence, when all PSII RCs are closed (P-step of OJIP transient)

$\mathrm{F}_{\mathrm{v}} \quad$ Variable fluorescence of the dark-adapted leaf

$\mathrm{F}_{\mathrm{v}} / \mathrm{F}_{\mathrm{m}} \quad$ Maximal quantum yield of PSII photochemistry

$\mathrm{V}_{\mathrm{J}} \quad$ Relative variable fluorescence at time $2 \mathrm{~ms}$ (J-step) after start of actinic light pulse

$\mathrm{V}_{\mathrm{I}} \quad$ Relative variable fluorescence at time $30 \mathrm{~ms}$ (I-step) after start of actinic light pulse

Area Area above the OJIP curve; it expresses the size of the reduced PQ pool

Quantum yields

$\Psi_{0} \quad$ Probability that a trapped exciton moves an electron into the electron transport chain beyond $\mathrm{Q}_{\mathrm{A}}$

$\Phi_{\text {Do }} \quad$ Quantum yield of energy dissipation

$\varphi_{\text {ET20 }} \quad$ Quantum yield of electron transport from $\mathrm{Q}_{\mathrm{A}}$ to $\mathrm{Q}_{\mathrm{B}}$ in PSII

$\varphi_{\text {RE10 }} \quad$ Quantum yield of reduction of end electron acceptors at the PSI acceptor side

$\mathrm{PI}_{\mathrm{abs}} \quad$ Performance index for the photochemical activity (basic formula on absorption basis)

$\mathrm{PI}_{\text {tot }} \quad$ Total performance index for the photochemical activity (including the flow beyond PSI)

Specific energy fluxes (per $\mathrm{Q}_{\mathrm{A}}$-reducing PSII reaction center)

$\mathrm{TR}_{0} / \mathrm{RC} \quad$ Trapped energy flux per $\mathrm{RC}($ at $\mathrm{t}=0)$

$\mathrm{ET}_{0} / \mathrm{RC} \quad$ Electron transport flux per $\mathrm{RC}($ at $\mathrm{t}=0)$

$$
\begin{aligned}
& \mathrm{F}_{0}=\mathrm{F}_{50 \mu \mathrm{s}} \\
& \mathrm{F}_{\mathrm{m}}=\mathrm{F}_{\mathrm{p}} \\
& \mathrm{F}_{\mathrm{v}}=\mathrm{F}_{\mathrm{m}}-\mathrm{F}_{0} \\
& \mathrm{~F}_{\mathrm{v}} / \mathrm{F}_{\mathrm{m}}=1-\left(\mathrm{F}_{0} / \mathrm{F}_{\mathrm{m}}\right) \\
& \mathrm{V}_{\mathrm{J}}=\left(\mathrm{F}_{2 \mathrm{~ms}}-\mathrm{F}_{0}\right) /\left(\mathrm{F}_{\mathrm{m}}-\mathrm{F}_{0}\right) \\
& \mathrm{V}_{\mathrm{I}}=\left(\mathrm{F}_{30 \mathrm{~ms}}-\mathrm{F}_{0}\right) /\left(\mathrm{F}_{\mathrm{m}}-\mathrm{F}_{0}\right)
\end{aligned}
$$

$\Psi_{0}=\left(1-\mathrm{V}_{\mathrm{J}}\right)$

$\Phi_{\mathrm{D}_{\mathrm{o}}}=\mathrm{F}_{0} / \mathrm{F}_{\mathrm{m}}$

$\varphi_{\mathrm{ET} 20}=\Phi_{\mathrm{Po}}\left(1-\mathrm{V}_{\mathrm{J}}\right)$

$\varphi_{\mathrm{RE} 10}=\Phi_{\mathrm{Po}}\left(1-\mathrm{V}_{\mathrm{I}}\right)$

$\mathrm{PI}_{\text {abs }}=\left[1-\left(\mathrm{F}_{0} / \mathrm{F}_{\mathrm{m}}\right)\right] /\left(\mathrm{M}_{0} / \mathrm{V}_{\mathrm{J}}\right) \times$

$\left(\mathrm{F}_{\mathrm{m}}-\mathrm{F}_{0}\right) / \mathrm{F}_{0} \times\left(1-\mathrm{V}_{\mathrm{J}}\right) / \mathrm{V}_{\mathrm{J}}$

$\mathrm{PI}_{\text {tot }}=\mathrm{PI}_{\text {abs }}\left(1-\mathrm{V}_{\mathrm{I}}\right) /\left(\mathrm{V}_{\mathrm{I}}-\mathrm{V}_{\mathrm{J}}\right)$ centrifuged at 3,500 rpm for $10 \mathrm{~min}$ and the supernatants were used. Then, $1 \mathrm{ml}$ of the extraction solution was mixed with $1 \mathrm{ml}$ of $2 \mathrm{~N}$ sulfuric acid. The mixture solution of 0.5 $\mathrm{ml}$ was poured into a tube and placed in cold water bath for $1 \mathrm{~h}$. Potassium iodide of $0.2 \mathrm{ml}$ (7.15 g iodide plus $20 \mathrm{~g}$ potassium iodide) was added to a tube and kept at $4^{\circ} \mathrm{C}$ for $14 \mathrm{~h}$, after which the samples were centrifuged at $10,000 \mathrm{rpm}$ for $15 \mathrm{~min}$. The granola crystals sediment was dissolved in $9 \mathrm{ml}$ of dichloromethane and was shaken and after $2 \mathrm{~h}$, samples were measured with a spectrophotometer at $365 \mathrm{~nm}$ (U-2000, Hitachi Instruments, Tokyo, Japan). The concentration of GB was calculated using the standard curve and the results were expressed as $\mu \mathrm{g} \mathrm{g}^{-1}(\mathrm{DM})$.

Elemental analysis: Samples of dry leaves were ground and dry-ashed at $550^{\circ} \mathrm{C}$ for $4 \mathrm{~h}$. The ashes were dissolved with $5 \mathrm{ml}$ of $2 \mathrm{~N} \mathrm{HCL}$ and made up to $50 \mathrm{ml}$ with distillated water. The concentrations of $\mathrm{Na}^{+}$and $\mathrm{K}^{+}$were measured by flame photometry. Analyses of $\mathrm{Ca}^{2+}$ and $\mathrm{Mg}^{2+}$ were carried out with an atomic absorption spectrophotometer (T80 $U V / V I S, G B C$ Avanta, China), $\mathrm{Cl}^{-}$was titrated with silver nitrate by Mohr method (Hong et al. 2011).
Experimental design and statistical analyses: This experiment was arranged as a factorial in the framework of a completely randomized design with two factors, salinity $(0,50$, and $100 \mathrm{mM}$ of $\mathrm{NaCl})$ and $\mathrm{GB}(0,50$, and $100 \mathrm{mM})$ with three replications. Analysis of variance $(A N O V A)$ was performed using the $S A S$ program (SAS Institute, Cary, NC, USA). Significant differences of the means $(P<0.05$ for $F$-test) were determined by $L S D$ 's multiple range test.

\section{Results}

Ion concentration: According to ANOVA results (Table 1), $\mathrm{Na}^{+}, \mathrm{Ca}^{2+}, \mathrm{K}^{+}$, and $\mathrm{Cl}^{-}$concentrations in cucumber plants were significantly affected by GB application and salinity stress. $\mathrm{Ca}^{2+}$ and $\mathrm{K}^{+}$concentrations severely declined by increasing salinity stress but the exogenous GB application increased the concentrations of these elements under salinity. The highest and the lowest $\mathrm{Ca}^{2+}$ and $\mathrm{K}^{+}$concentrations were observed at $\mathrm{GB}(100 \mathrm{mM})$ under the control conditions and GB (0 mM salinity) under salinity (100 $\mathrm{mM}$ ) condition treatments, respectively (Table 1). Leaf $\mathrm{Cl}^{-}$and $\mathrm{Na}^{+}$concentrations of cucumber plants grown with Hoagland solution ( $0 \mathrm{mM}$ salinity) in addition to GB were 
Table 1. Effect of salinity (S) and glycine betaine (GB) on leaf ion concentrations $\left(\mathrm{Na}^{+}, \mathrm{Ca}^{2+}, \mathrm{K}^{+}\right.$, and $\left.\mathrm{Cl}^{-}\right)$and leaf osmotic regulating compounds (proline, GB - glycine betaine; TSC - total soluble carbohydrate) of cucumber plants. DM - dry mass; Df - degree of freedom; Error - the dispersion ratio occurs by uncontrollable factors in the test. Values are means \pm SE of three replicates. Different letters in each column show significant differences at $P \leq 0.05(L S D)$. Mean squares are used in analysis of variance and are calculated as a sum of squares divided by their appropriate degrees of freedom. ${ }^{*}$ - significance at $\left.P \leq 0.05\right) ; * *$ significance at $P \leq 0.01 ; \mathrm{CV}-$ coefficient of variation.

\begin{tabular}{|c|c|c|c|c|c|c|c|c|}
\hline $\begin{array}{l}\text { Salinity } \\
{[\mathrm{mM}(\mathrm{NaCl})]}\end{array}$ & $\begin{array}{l}\mathrm{GB} \\
{[\mathrm{mM}]}\end{array}$ & $\begin{array}{l}\mathrm{Na}^{+} \\
{[\%(\mathrm{DM})]}\end{array}$ & $\begin{array}{l}\mathrm{Ca}^{2+} \\
{[\%(\mathrm{DM})]}\end{array}$ & $\begin{array}{l}\mathrm{K}^{+} \\
{[\%(\mathrm{DM})]}\end{array}$ & $\begin{array}{l}\mathrm{Cl}^{-} \\
{[\%(\mathrm{DM})]}\end{array}$ & $\begin{array}{l}\text { TSC } \\
{\left[\mathrm{mg} \mathrm{g}^{-1}(\mathrm{FM})\right]}\end{array}$ & $\begin{array}{l}\text { Proline } \\
{\left[\mathrm{mg} \mathrm{g}^{-1}(\mathrm{FM})\right]}\end{array}$ & $\begin{array}{l}\mathrm{GB} \\
{\left[\mu \mathrm{g} \mathrm{g}^{-1}(\mathrm{DM})\right]}\end{array}$ \\
\hline \multirow[t]{3}{*}{0} & 0 & $0.23 \pm 0.02^{\mathrm{e}}$ & $0.42 \pm 0.01^{\mathrm{d}}$ & $1.36 \pm 0.02^{\mathrm{c}}$ & $0.70 \pm 0.03^{\text {cd }}$ & $0.50 \pm 0.03^{\mathrm{e}}$ & $0.67 \pm 0.02^{\mathrm{h}}$ & $1.25 \pm 0.02^{\mathrm{g}}$ \\
\hline & 50 & $0.19 \pm 0.03^{\mathrm{f}}$ & $0.48 \pm 0.02^{\mathrm{bc}}$ & $1.56 \pm 0.03^{\mathrm{b}}$ & $0.68 \pm 0.01^{\mathrm{de}}$ & $0.63 \pm 0.02^{\mathrm{d}}$ & $0.89 \pm 0.03^{\mathrm{g}}$ & $1.36 \pm 0.01^{\mathrm{f}}$ \\
\hline & 100 & $0.12 \pm 0.02^{\mathrm{g}}$ & $0.59 \pm 0.01^{\mathrm{a}}$ & $1.74 \pm 0.02^{\mathrm{a}}$ & $0.59 \pm 0.01^{\mathrm{e}}$ & $0.63 \pm 0.02^{\mathrm{d}}$ & $0.97 \pm 0.01^{\mathrm{f}}$ & $1.58 \pm 0.02^{\mathrm{e}}$ \\
\hline \multirow[t]{3}{*}{50} & 0 & $0.35 \pm 0.01^{\mathrm{c}}$ & $0.40 \pm 0.00^{\mathrm{d}}$ & $1.19 \pm 0.01^{\mathrm{e}}$ & $0.88 \pm 0.02^{\mathrm{b}}$ & $0.65 \pm 0.15^{\mathrm{d}}$ & $1.09 \pm 0.01^{\mathrm{e}}$ & $2.43 \pm 0.03^{\mathrm{d}}$ \\
\hline & 50 & $0.33 \pm 0.01^{\mathrm{cd}}$ & $0.47 \pm 0.02^{\mathrm{c}}$ & $1.22 \pm 0.01^{\mathrm{de}}$ & $0.79 \pm 0.03^{b c}$ & $0.67 \pm 0.01^{\mathrm{cd}}$ & $1.02 \pm 0.03^{\mathrm{d}}$ & $2.66 \pm 0.06^{\mathrm{c}}$ \\
\hline & 100 & $0.31 \pm 0.01^{\mathrm{d}}$ & $0.50 \pm 0.01^{\mathrm{b}}$ & $1.26 \pm 0.01^{\mathrm{d}}$ & $0.73 \pm 0.15^{\mathrm{cd}}$ & $0.72 \pm 0.008^{\mathrm{bc}}$ & $1.28 \pm 0.04^{\mathrm{c}}$ & $2.89 \pm 0.03^{b}$ \\
\hline \multirow[t]{3}{*}{100} & 0 & $0.63 \pm 0.03^{\mathrm{a}}$ & $0.31 \pm 0.01^{\mathrm{e}}$ & $1.01 \pm 0.01^{\mathrm{g}}$ & $1.11 \pm 0.01^{\mathrm{a}}$ & $0.71 \pm 0.02^{\mathrm{bc}}$ & $1.34 \pm 0.04^{\mathrm{c}}$ & $4.02 \pm 0.02^{\mathrm{a}}$ \\
\hline & 50 & $0.50 \pm 0.01^{\mathrm{b}}$ & $0.41 \pm 0.01^{\mathrm{d}}$ & $1.10 \pm 0.01^{\mathrm{f}}$ & $0.87 \pm 0.07^{\mathrm{b}}$ & $0.75 \pm 0.02^{\mathrm{b}}$ & $1.50 \pm 0.04^{\mathrm{b}}$ & $4.02 \pm 0.01^{\mathrm{a}}$ \\
\hline & 100 & $0.47 \pm 0.01^{\mathrm{b}}$ & $0.47 \pm 0.06^{c}$ & $1.18 \pm 0.03^{\mathrm{e}}$ & $0.76 \pm 0.03^{\mathrm{cd}}$ & $0.84 \pm 0.03^{\mathrm{a}}$ & $1.70 \pm 0.03^{\mathrm{a}}$ & $4.13 \pm 0.01^{\mathrm{a}}$ \\
\hline Source of variations & Df & \multicolumn{7}{|c|}{ Mean squares } \\
\hline Salinity (S) & 2 & $0.281^{* *}$ & $0.022^{* *}$ & $0.500^{* *}$ & $0.150^{* *}$ & $0.080^{* *}$ & $1.011^{* *}$ & $15.931^{* *}$ \\
\hline GB & 2 & $0.030^{* *}$ & $0.045^{* *}$ & $0.090^{* *}$ & $0.090^{* *}$ & $0.030^{* *}$ & $0.181^{* *}$ & $0.201^{* *}$ \\
\hline $\mathrm{S} \times \mathrm{GB}$ & 4 & $0.004^{* *}$ & $0.001^{* *}$ & $0.018^{*}$ & $0.014^{*}$ & $0.003^{*}$ & $0.008^{*}$ & $0.021^{*}$ \\
\hline Error & 18 & 0.0004 & 0.001 & 0.001 & 0.003 & 0.001 & 0.002 & 0.004 \\
\hline $\mathrm{CV}[\%]$ & & 6.240 & 3.730 & 2.600 & 7.090 & 5.010 & 3.530 & 2.340 \\
\hline
\end{tabular}

found to be significantly lower than that in plants without GB. Also, the results indicated that the concentrations of $\mathrm{Cl}^{-}$and $\mathrm{Na}^{+}$increased with increasing level of salt stress but GB treatment reduced the accumulation and toxicity of these elements under salinity conditions (Table 1).

Osmotic regulating compounds: The results indicated that salinity, GB, and their interaction had a significant effect on osmotic regulating compounds, such as soluble sugar, proline, and GB (Table 1). Soluble sugar, proline, and GB were increased by the saline treatment compared with the control. The plants treated with GB also showed the higher content of soluble sugar, proline, and GB as compared to the control ones. The highest content of these compounds was observed in plants treated with GB under high level of salinity $(100 \mathrm{mM})$ and the lowest soluble sugar, proline, and GB contents were recorded in plants grown under control conditions and without GB application (Table 1).

Pigment content: Total Chl, Chl $a, b$, and Car contents in leaves of cucumber plants were significantly affected by salinity stress, GB, and their interaction effects (Table 1S, supplement). Salt stress significantly reduced total Chl, Chl $a, b$, and Car contents in leaves compared with the control treatment. GB application improved these traits both under salinity and control conditions. The highest total Chl, Chl $a, b$, and Car contents were observed in $100 \mathrm{mM} \mathrm{GB}$ treatment under control conditions and the respective lowest ones were recorded under salinity $(100 \mathrm{mM} \mathrm{NaCl})$ treatment without GB (Fig. 1). The results also showed that Chl $a$ was more affected than other photosynthetic pigments under salinity stress. Thus, the amount of Chl $a$ decreased by $36.1 \%$ compared with the control treatment (Table 1S, supplement).

Chl fluorescence: All Chl fluorescence parameters of cucumber leaves measured in this experiment $\left(\mathrm{F}_{\mathrm{v}}, \mathrm{F}_{\mathrm{m}}, \mathrm{F}_{0}\right.$, $\mathrm{F}_{\mathrm{v}} / \mathrm{F}_{\mathrm{m}}$, Area, $\mathrm{V}_{\mathrm{I}}$, and $\mathrm{V}_{\mathrm{J}}$ ) were affected by salinity, GB application, and their combination (Table $2 \mathrm{~S}$, supplement). The value of $F_{m}, F_{v}, F_{v} / F_{m}$, and Area decreased under salinity conditions but the GB application diminished the effect of salinity on these parameters these parameters (Fig. 2B-D). The results of $\mathrm{Chl}$ fluorescence also showed that salinity increased $\mathrm{F}_{0}$ and $\mathrm{V}_{\mathrm{J}}$ but the use of GB affected differently these parameters. Thus, the application of $\mathrm{GB}$ decreased $\mathrm{F}_{0}$ under salinity and control conditions (6.3 and 5\%, respectively) (Fig. 2A). A gradual promotion of $\mathrm{V}_{\mathrm{J}}$ was observed after application of GB (Fig. 2E). Plants treated with $100 \mathrm{mM} \mathrm{GB}$ under high level of salinity $(100 \mathrm{mM} \mathrm{NaCl})$ showed maximum $\mathrm{V}_{\mathrm{I}}$; the minimum $\mathrm{V}_{\mathrm{I}}$ was recorded under control conditions with $50 \mathrm{mM} \mathrm{GB}$ (Fig. 2F).

Quantum yields and specific energy fluxes, including $\Psi_{0}$, $\Phi_{\text {Do }}, \varphi_{\text {ET20 }}, \varphi_{\text {RE } 10}, \mathrm{PI}_{\text {abs }}, \mathrm{PI}_{\text {tot }}$, and TR $0 /$ RC were influenced by salinity, GB, and their interactions significantly (Table 2). $\Psi_{0}, \varphi_{\mathrm{ET} 20}, \varphi_{\mathrm{RE} 10}, \mathrm{PI}_{\text {abs }}, \mathrm{PI}_{\text {tot }}$, and $\mathrm{TR}_{0} / \mathrm{RC}$ decreased with increasing salinity, but foliar applications of GB decreased toxicity effect of salinity on these parameters (Table 2). Contrarily, the value of $\Phi_{\text {Do }}$ increased with increasing salinity, while the GB application reduced the effect of salinity by decreasing the value of $\Phi_{\mathrm{D}}$, so the maximum and minimum $\Phi_{\text {Do }}$ were observed under $100 \mathrm{mM} \mathrm{NaCl}$ without GB and under $100 \mathrm{mM}$ GB without salt stress, respectively (Table 2 ). 

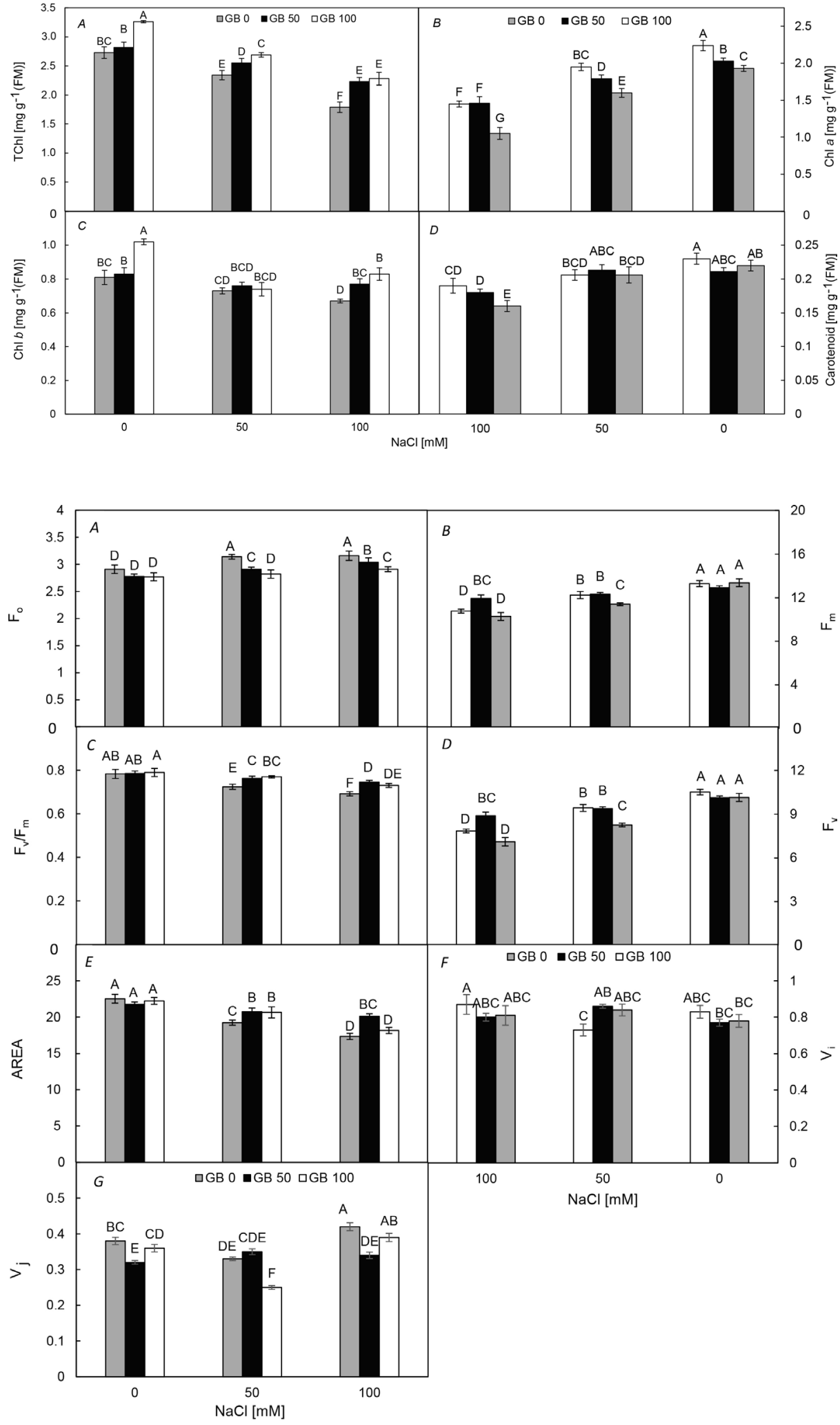

Fig. 1. Effect of salinity and glycine betaine (GB) on total chlorophyll (TChl) $(A)$, chlorophyll (Chl) $a(B)$, Chl $b(C)$, and carotenoid $(D)$ content of cucumber plants. Bars indicate standard error. Columns with different letters are significantly different at $P \leq 0.05$.

Fig. 2. Effect of salinity and glycine betaine (GB) on Chl fluorescence parameters of cucumber plants. Bars indicate standard error. Columns with different letters are significantly different at $P \leq 0.05 . \mathrm{F}_{0}-$ minimal fluorescenceyield of the dark-adapted state; $F_{m}$ - maximal fluorescence of the dark-adapted state; $F_{v}-$ maximal variable fluorescence; $\mathrm{F}_{\mathrm{v}} / \mathrm{F}_{\mathrm{m}}$ maximal quantum yield of PSII photochemistry; $\mathrm{V}_{\mathrm{I}}-$ relativevariable fluorescence at time $30 \mathrm{~ms}$ (I-step) after start of actinic light pulse; $\mathrm{V}_{\mathrm{J}}-$ relative variable fluorescence at J-step.

Dry mass: We found significance of interaction between salinity and GB treatment in the case of total dry mass. A positive growth response due to foliar application of GB was observed in all cucumber plants. The highest value of
DM was recorded after $100 \mathrm{mM} \mathrm{GB}$ application on plants grown without salt stress, while the lower value of DM was noted under $100 \mathrm{mM} \mathrm{NaCl}$ without $\mathrm{GB}$ application (Fig. 3). 


\section{Discussion}

Ion concentration: Aggregation of specific ions under salinity conditions caused nutritional imbalances in plant tissues (Ferguson and Grattan 2005). In our experiment, the salt treatment resulted in a reduction of $\mathrm{Ca}^{2+}$ and $\mathrm{K}^{+}$ concentrations but a great increase in $\mathrm{Cl}^{-}$and $\mathrm{Na}^{+}$concentrations in aerial parts of cucumber plants. Changes in a mineral content have been also reported in spinach (Chow et al. 1990), pepper (Rubio et al. 2003), and cucumber (Trajkova et al. 2006), which supported our findings. Salinity reduces the absorption of water and nutrients by changing the operating root ion channel, such as $\mathrm{K}^{+}$ channels, or inhibit root growth through osmotic effect of $\mathrm{Na}^{+}$(Parida and Das 2005, Zhu 2007). Tavakkoli et al. (2010) suggested that the amount of potassium seems to be dependent on $\mathrm{Na}^{+}$accumulation because there is an antagonistic effect between $\mathrm{K}^{+}$and $\mathrm{Na}^{+}$cations. According

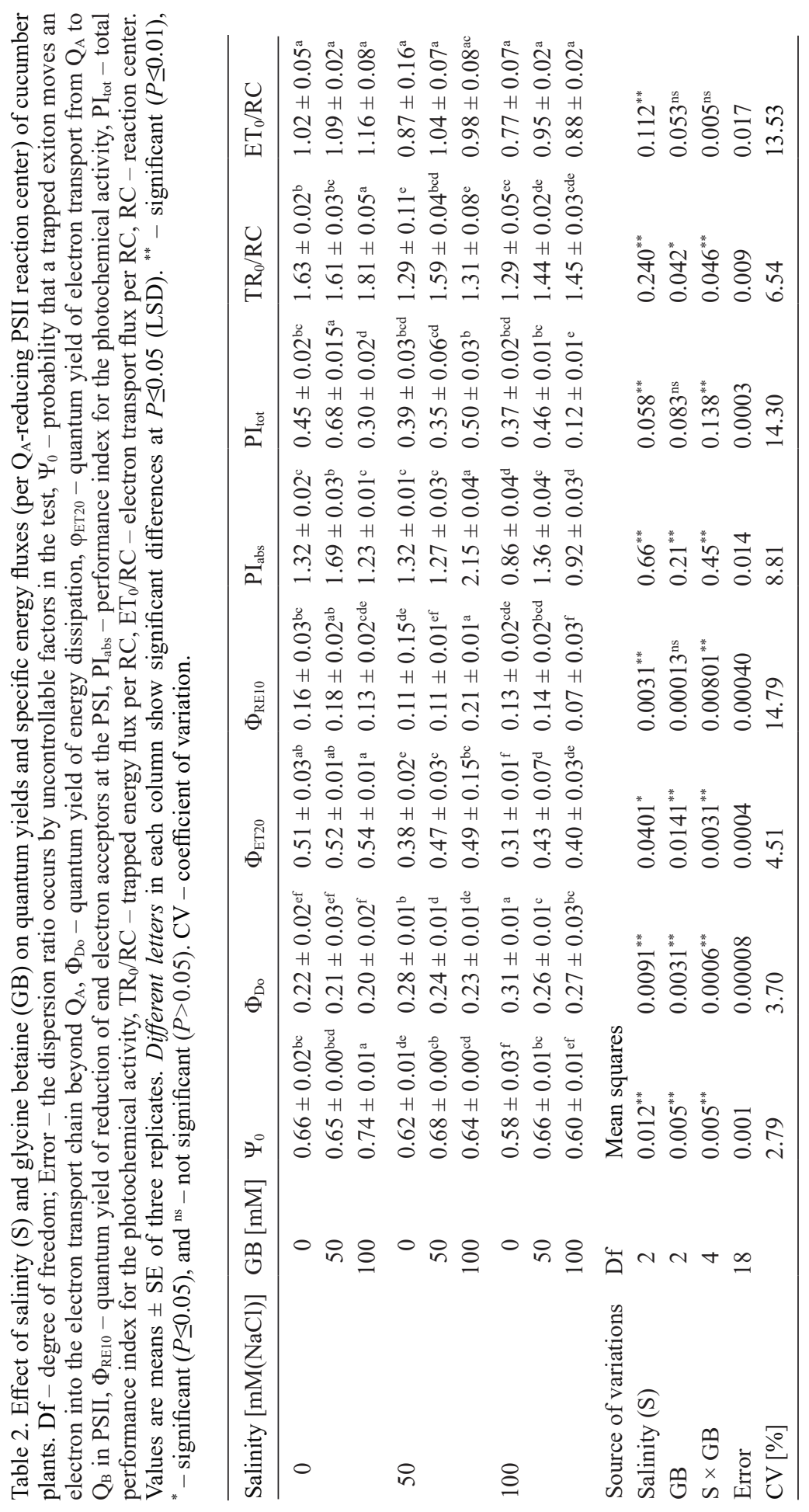




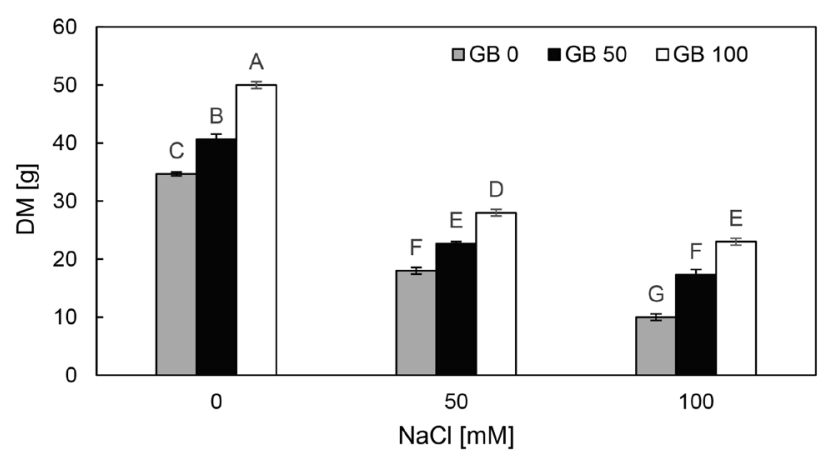

Fig. 3. Effect of salinity and glycine betaine $(\mathrm{GB})$ on total dry mass (DM) of cucumber plants. Bars indicate standard error. Columns with different letters are significantly different at $P \leq 0.05$.

to our results, $\mathrm{Ca}^{2+}$ and $\mathrm{K}^{+}$contents increased both in saline and nonsaline conditions with increasing GB compared to those without GB application and enhanced $\mathrm{Na}^{+}$and $\mathrm{Cl}^{-}$toxicity. GB treatment induced a generation of extra vacuoles in root cells, which resulted in aggregation of $\mathrm{Na}^{+}$in the roots and a decrease in its transportation to the shoots (Rahman et al. 2002). Structural changes, such as enhancement in the number of mitochondria in the cytoplasm of the root tip, were observed with application of GB under salt stress (Ashraf and Foolad 2007). In a study carried out by Rahman et al. (2002), GB application lowered $\mathrm{Na}^{+}$and enhanced $\mathrm{K}^{+}$content in the aerial parts of salt-stressed rice plants.

Osmotic regulating compounds: Exogenous application of GB can rapidly reach an increasing plant stress tolerance by accumulation of osmo-regulators in plant tissue. For example, foliar application resulted in a significant improvement in salt tolerance of rice plants (Lutts 2000). In the current study, salinity gradually enhanced soluble sugar, proline, and GB contents. These finding were in agreement with the study of Sakr et al. (2012). Generally, when plants experience stress conditions, they regulate their cell osmotic potential by production of organic compounds such as proline and soluble sugars (Ashraf and McNeilly 2004). Accumulation of soluble organic compounds and lowmolecular-mass organic solutes, such as osmoregulators, is one of mechanisms that many plant species use to reduce the negative effects of water deficit and salt stress (Chaves et al. 2003). Overproduction of osmolytes such as GB and proline under salinity stress resulted in protection of thylakoids membranes and improvement of the stability of some cytoplasmic and mitochondrial enzymes (Genard et al. 1991). In this study, GB treatment increased osmoregulators both under salinity stress and control conditions. This result is supported by the outcomes of Cha-um et al. (2006) on rice and Sakr et al. (2012) on canola, where the application of GB increased osmoregulators in plant tissue under salinity stress.

Photosynthetic pigments: Reduction in Chl and other photosynthetic pigments at high $\mathrm{NaCl}$ concentration might occur due to the destruction of chloroplasts or changes in thylakoid membrane structure (Iyengar and Reddy 1996). Reduction in Chl content may be due to the loss of specific enzymes that play an important role in biosynthesis of such pigments (Murkute et al. 2006). The reduction of Chl content could occur due to a greater activity of chlorophyllase under stress conditions (Woodward and Bennett 2005). Car act as auxiliary pigments and as effective antioxidants for the protection and stability of photochemical processes (Abbasi et al. 2014). Several investigations have described that salinity significantly decreased the photosynthetic pigments ( $\mathrm{Li}$ et al. 2010). These results corresponded with our finding on cucumber plants. The application of organic compounds such as GB on the cucumber plants increased photosynthetic pigments in leaves of these plants compared with control plants under salinity and nonsalinity conditions. Although, the physiological effect of GB is not clear, recent research showed that GB plays a key role similar to cytokinine in enhancing the Chl content (Makela et al. 2000). On the other hand, Genard et al. (1991) reported that GB has a major role in protecting chloroplasts and thylakoid membrane from oxidative damage under stress conditions. The results of this investigation are corresponding to those of Park et al. (2006) who believed that Chl content of tomato leaves was increased by GB treatment.

Chl fluorescence measurement is one of the critical, simple, and nondestructive methods to assess the efficiency of photosynthesis (Brestič and Živčák 2013). Plant response to salinity depends on PSII ability to respond to this stress. It has been reported that salinity reduces the quantum yield of PSII electron transport, the amount of light energy that reaches the reaction centers, and the oxygen-evolving complex (Kalaji et al. 2011). When plastoquinone (PQ) was oxidized, the system of electron transport had the lowest $\mathrm{F}_{0}$, but under stress conditions, $F_{0}$ increased due to the change in thylakoid membrane structure and damage to reaction centers of PSII (Wright et al. 2009). The maximum quantum yield of PSII photochemistry $\left(\mathrm{F}_{\mathrm{v}} / \mathrm{F}_{\mathrm{m}}\right)$ is frequently used as an indicator of photoinhibition or of other types of stresses caused to PSII (Baker 2008). Reduction in $F_{m}, F_{v}$, and $F_{v} / F_{m}$ under stress conditions could prevent transfer of electrons from PSII reaction center to electron transporters (Mehta et al. 2010). In addition, the capacity of PQ pool (Area) was reduced under stress conditions, and then the electron transport significantly decreased (Misra et al. 2001). Li et al. (2010) reported that $\mathrm{F}_{\mathrm{m}}, \mathrm{F}_{\mathrm{v}}$, and $\mathrm{F}_{\mathrm{v}} / \mathrm{F}_{\mathrm{m}}$ decreased with increasing salinity, as indicated salinity-enhanced $F_{0}$ in castor bean plants. Oraei et al. (2009) suggested that the concentrations of $\mathrm{K}^{+}$and $\mathrm{Mg}^{2+}$ (the main elements in the synthesis of $\mathrm{Chl}$ ) decreased under salinity conditions that damaged the Chl structures and finally decreased the ratio of $F_{v} / F_{m}$. Energy dissipation $\left(\Phi_{D o}\right)$ is enhanced under stress conditions due to inactivation of some PSII reaction centers (RCs) (Kalaji et al. 2014). Reduction of $\mathrm{PI}_{\mathrm{abs}}$ and $\mathrm{PI}_{\text {tot }}$ under stress conditions suggested reduction in overall performance of photosynthesis linked to decrease of electron transport capacity. These results were consistent with our results. 
It seems that GB increased the efficiency of photosynthesis by maintaining chloroplasts and thylakoid membrane structures (Brestič and Živčák 2013). Further work is necessary to investigate the effect of GB on Chl fluorescence and photosynthetic electron transport chain.

Dry mass: We observed a negative effect of salinity on DM. Reduction of the DM under salt stress could be due to decreased osmotic potential of plant cells. However, the root cells could not absorb water needed for growth. As a result, plant growth and plant DM under such conditions is reduced (Çiçek and Çakirlar 2002). The results of this study also indicated that GB application improved response to salinity. It seems that, under stress conditions, the accumulation of GB in cytoplasm maintains the plant cells osmotic potential. This in turn improves plants photosynthetic performance, growth and finally rises their DM (Volkmar et al. 1997).

Correlation analysis showed that the GB content was significantly correlated with all measured parameters except for parameter $\varphi_{\mathrm{ET} 20}$ (quantum yield of electron transport from $\mathrm{Q}_{\mathrm{A}}$ to $\mathrm{Q}_{\mathrm{B}}$ in PSII) (data not shown). However, positive correlations were found only with the following parameters: proline, TSC, $\Phi_{\mathrm{Do}}, \Psi_{0}$, and $\mathrm{V}_{\mathrm{I}}$. This indicates that the GB content has a very important role in photosynthetic machinery control/adaptation to salinity.

In conclusion, the results of this experiment showed that GB application significantly improved the salt stress responses in cucumber plants. This result suggests that GB could be used as an organic osmolyte regulator to improve photosynthetic pigment contents and photosynthetic performance, quantum yield and energy fluxes between PSII and PSI reaction centers under $\mathrm{NaCl}$ stress.

\section{References}

Abbasi A.R., Sarvestani R., Mohammadi B., Baghery A.: Drought stress-induced changes at physiological and biochemical levels in some common vetch (Vicia sativa L.) genotypes. J. Agr. Sci. Tech. 16: 505-516, 2014.

Arakawa K., Katayama M., Takabe T.: Levels of betaine and betaine aldehyde dehydrogenase activity in the green leaves, and etiolated leaves and roots of barley.-Plant Cell Physiol. 31: 797-803, 1990

Ashraf M., Foolad M.: Roles of glycine betaine and proline in improving plant abiotic stress resistance. - Environ. Exp. Bot. 59: 206-216, 2007.

Ashraf M., McNeilly T.: Salinity tolerance in Brassica oilseeds. Crit. Rev. Plant Sci. 23: 157-174, 2004.

Baker N.R.: Chlorophyll fluorescence: a probe of photosynthesis in vivo. - Annu. Rev. Plant Biol. 59: 89-113, 2008.

Brestič M., Živčák M.: PSII fluorescence techniques for measurement of drought and high temperature stress signal in crop plants: protocols and applications. - In: Rout G., Das A. (ed.): Molecular Stress Physiology of Plants. Pp. 87-131. Springer, India 2013.

Cha-um S., Supaibulwatana K., Kirdmanee C.: Water relation, photosynthetic ability and growth of thai jasmine rice (Oryza sativa L. ssp. indica cv. KDML 105) to salt stress by application of exogenous glycinebetaine and choline. J. Agron. Crop Sci. 192: 25-36, 2006.

Chaves M.M., Maroco J.P., Pereira J.S.: Understanding plant responses to drought - From genes to the whole plant. Funct. Plant Biol. 30: 239-264, 2003.

Chow W.S., Ball M.C., Anderson J.M.: Growth and photosynthetic responses of spinach to salinity: implications of $\mathrm{K}^{+}$nutrition for salt tolerance. - Aust. J. Plant Physiol. 17: 563-578, 1990.

Çiçek N., Çakirlar H.: The effect of salinity on some physiological parameters in two maize cultivars. - Bulg. J. Plant Physiol. 28: 66-74, 2002

Cramer G.R., Schmidt C.L., Bidart C.: Analysis of cell hardening and wall enzymes of salt stressed maize (Zea mays) leaves. Aust. J. Plant Physiol. 28: 101-109, 2001.

De Las Rivas J., Barber J.: Structure and thermal stability of photosystem II reaction centers studied by infrared spectroscopy. - Biochemistry 36: 8997-8903, 1997.

Denaxa N.K., Roussos P.A., Damvakaris T., Stournaras V.: Comparative effects of exogenous glycine betaine, kaolin clay particles and Ambiol on photosynthesis, leaf sclerophylly indexes and heat load of olive cv. Chondrolia Chalkidikis under drought. - Sci. Hortic.-Amsterdam 137: 87-94, 2012.

Estaji A., Roosta H.R., Rezaei S.A. et al.: Morphological, physiological and phytochemical response of different Satureja hortensis L. accessions to salinity in a greenhouse experiment. - JARMAP 10: 25-33, 2018.

Ferguson L., Grattan S.R.: How salinity damages citrus: osmotic effects and specific ion toxicities. - HortTechnology 15: 95-99, 2005.

Gadallah M.A.A.: Effects of proline and glycinebetaine on Vicia faba responses to salt stress. - Biol. Plantarum 42: 249-257, 1999.

Genard H., Le Saos J., Hillard J. et al.: Effect of salinity on lipid composition, glycine betaine content and photosynthetic activity in chloroplasts of Suaeda maritima. - Plant Physiol. Bioch. 29: 421-427, 1991.

Hong T.K., Kim M.H., Czae M.Z.: Determination of chlorinity of water without the use of chromate indicator. - Int. J. Anal. Chem. 2010: 602939, 2011.

Hussain M.I., Reigosa M.J.: A chlorophyll fluorescence analysis of photosynthetic efficiency, quantum yield and photon energy dissipation in PSII antennae of Lactuca sativa L. leaves exposed to cinnamic acid. - Plant Physiol. Bioch. 49: 1290-1298, 2011.

Iyengar E.R.R., Reddy M.P.: Photosynthesis in highly salt tolerant plants. - In: Pessarakli M. (ed.): Handbook of Photosynthesis. Pp. 897-910. Marcel Dekker, New York-Basel 1996.

Kalaji H.M., Govindjee, Bosa K. et al.: Effects of salt stress on photosystem II efficiency and $\mathrm{CO}_{2}$ assimilation of two Syrian barley landraces. - Environ. Exp. Bot. 73: 64-72, 2011.

Kalaji H.M., Oukarroum A., Alexandrov V. et al.: Identification of nutrient deficiency in maize and tomato plants by in vivo chlorophyll a fluorescence measurements. - Plant Physiol. Bioch. 81: 16-25, 2014.

Kautsky H., Hirsch A.: [Neue Versuche zur Kohlensäureassimilation]. - Naturwissenschaften 19: 964, 1931. [In German]

Li G., Wan S., Zhou J. et al.: Leaf chlorophyll fluorescence, hyperspectral reflectance, pigments content, malondialdehyde and proline accumulation responses of castor bean (Ricinus communis L.) seedlings to salt stress levels. - Ind. Crop. Prod. 31: 13-19, 2010.

Lichtenthaler R.: Chlorophylls and carotenoids pigments of photosynthetic biomembranes. - Method. Enzymol. 148: 350-382, 1987.

Lutts S.: Exogenous glycine betaine reduces sodium accumulation in salt-stressed rice plants. Int. Rice Res. Notes 25: 39-40, 2000.

Makela P., Kärkkäinen J., Somersalo S.: Effect of glycinebetaine on chloroplast ultrastructure, chlorophyll and protein content, 
and RuBPCO activities in tomato grown under drought or salinity. - Biol. Plantarum 43: 471-475, 2000.

Mehta P., Jajoo A., Mathur S., Bharti S.: Chlorophyll a fluorescence study revealing effects of high salt stress on PS II in wheat leaves. - Plant Physiol. Bioch. 48: 16-20, 2010.

Misra A.N., Srivastava A., Strasser R.J.: Utilization of fast chlorophyll $a$ fluorescence technique in assessing the salt/ ion sensitivity of mug bean and Brassica seedlings. - J. Plant Physiol. 158: 1173-1181, 2001.

Murkute A., Sharma S., Singh S.: Studies on salt stress tolerance of citrus rootstock genotypes with arbuscular mycorrhizal fungi. - Hortic. Sci. 33: 70-76, 2006.

Oraei M., Tabatabaei S.J., Fallahi E., Imani A.: The effects of salinity stress and rootstock on the growth, photosynthetic rate, nutrient and sodium concentration of almond (Prunus dulcis Mill.). - J. Hortic. Sci. 23: 121-140, 2009.

Osório J., Osório M.L., Correia P.J. et al.: Chlorophyll fluorescence imaging as a tool to understand the impact of iron deficiency and resupply on photosynthetic performance of strawberry plants. - Sci. Hortic.-Amsterdam 165: 148-155, 2014.

Paquin R., Lechasseur P.: [Studies of a method for the determination of free proline content in plant extracts.] - Can. J. Bot. 57: 1851-1854, 1979. [In French]

Parida A.K., Das A.B.: Salt tolerance and salinity effects on plants: a review. - Ecotox. Environ. Safe. 60: 324-349, 2005.

Park E.J., Jeknic Z., Chen T.H.: Exogenous application of glycinebetaine increases chilling tolerance in tomato plants. Plant Cell Physiol. 47: 706-714, 2006.

Percival G.C., Henderson A.: An assessment of the freezing tolerance of urban trees using chlorophyll fluorescence. - J. Hort. Sci. Biotech. 78: 254-260, 2003.

Petridis A., Therios I., Samouris G. et al.: Effect of water deficit on leaf phenolic composition, gas exchange, oxidative damage and antioxidant activity of four Greek olive (Olea europaea L.) cultivars. - Plant Physiol. Bioch. 60: 1-11, 2012.

Rahman M.S., Miyake H., Takeoka Y.: Effects of exogenous glycine betaine on growth and ultrastructure of salt-stressed rice seedlings (Oryza sativa L.). - Plant Prod. Sci. 5: 33-44, 2012.

Razavi F., Pollet B., Steppe K., van Labeke M.C.: Chlorophyll fluorescence as a tool for evaluation of drought stress in strawberry. - Photosynthetica 46: 631-633, 2008.

Roosta H.R., Estaji A., Niknam F.: Effect of iron, zinc and manganese shortage-induced change on photosynthetic pigments, some osmoregulators and chlorophyll fluorescence parameters in lettuce. - Photosynthetica 56: 606-615, 2018.

Rubio F., Flores P., Navarro J.M. et al:: Effects of $\mathrm{Ca}^{2+}, \mathrm{K}^{+}$ and cGMP on $\mathrm{Na}^{+}$uptake in pepper plants. - Plant Sci. 165: 1043-1049, 2003.

Sakr M.T., El-Sarkassy N.M., Fuller M.P.: Osmoregulators proline and glycine betaine counteract salinity stress in canola. - Agron. Sustain. Dev. 32: 747-754, 2012.

Serraj R., Sinclair T.R.: Osmolyte accumulation: can it really help increase crop yield under drought conditions? - Plant Cell Environ. 25: 333-341, 2002.

Sharkey T.D., Zhang R.: High temperature effects on electron and proton circuits of photosynthesis. - J. Integr. Plant Biol. 52: 712-722, 2010.

Stepien P., Klobus G.: Water relations and photosynthesis in Cucumis sativus L. leaves under salt stress. - Biol. Plantarum 50: 610-616, 2006.

Stirbet A., Lazár D., Kromdijk J., Govindjee: Chlorophyll $a$ fluorescence induction: Can just a one-second measurement be used to quantify abiotic stress responses? - Photosynthetica 56: 86-104, 2018.

Strasser R., Srivastava A., Tsimilli-Michael M.: The fluorescence transient as a tool to characterize and screen photosynthetic samples. - In: Yunus M., Pathre U., Mohanty P. (ed.): Probing Photosynthesis: Mechanisms, Regulation and Adaptation. Pp. 445-483. Taylor \& Francis, London 2000.

Strasser R.J., Srivastava A., Tsimilli-Michael M.: Analysis of the chlorophyll $a$ fluorescence transient. - In: Papageorgiou G.C., Govindjee (ed.): Chlorophyll $a$ Fluorescence: A Signature of Photosynthesis. Advances in Photosynthesis and Respiration. Pp. 321-362. Springer, Dordrecht 2004.

Tavakkoli E., Rengasamy P., McDonald G.K.: High concentrations of $\mathrm{Na}^{+}$and $\mathrm{Cl}^{-}$ions in soil solution have simultaneous detrimental effects on growth of faba bean under salinity stress. - J. Exp. Bot. 61: 4449-4459, 2010.

Trajkova F., Papadantonakis N., Savvas D.: Comparative effects of $\mathrm{NaCl}$ and $\mathrm{CaCl}_{2}$ salinity on cucumber grown in a closed hydroponic system. - HortScience 41: 437-441, 2006.

Vassileva V., Demirevska K., Simova-Stoilova L. et al.: Longterm field drought affects leaf protein pattern and chloroplast ultrastructure of winter wheat in a cultivar-specific manner. J. Agron. Crop Sci. 198: 104-117, 2012.

Volkmar K.M., Hu Y., Steppuhn H.: Physiological response of plant to salinity: a review. - Can. J. Plant Sci. 78: 19-27, 1997.

Woodward A.J., Bennett I.J.: The effect of salt stress and abscisic acid on proline production, chlorophyll content and growth of in vitro propagated shoots of Eucalyptus camaldulensis. Plant Cell Tiss. Org. 82: 189-200, 2005.

Wright A.H., DeLong J.M., Lada R.R., Prange R.K.: The relationship between water status and chlorophyll $a$ fluorescence in grapes (Vitis spp.). - Postharvest Biol. Tec. 51: 193-199, 2009.

Xia J., Li Y., Zou D.: Effects of salinity stress on PSII in Ulva lactuca as probed by chlorophyll fluorescence measurements. - Aquat. Bot. 80: 129-137, 2004.

Yang W.J., Rich P.J., Axtell J.D. et al.: Genotypic variation for glycine betaine in sorghum. - Crop Sci. 43: 162-169, 2003.

Zhao G.Q., Ma B.L., Ren C.Z.: Growth, gas exchange, chlorophyll fluorescence, and ion content of naked oat in response to salinity. - Crop Sci. 47: 123-131, 2007.

Zhu J.K.: Plant salt stress. - In: O'Daly A. (ed.): Encyclopedia of Life Sciences. Pp. 3. John Wiley \& Sons Ltd., Chichester 2007.

(C) The authors. This is an open access article distributed under the terms of the Creative Commons BY-NC-ND Licence. 